\title{
FAKTOR INDIVIDU YANG MEMPENGARUHI KELENGKAPAN DOKUMENTASI DALAM ASUHAN KEPERTAWATAN
}

\author{
Helena Gultom
}

\author{
Email : helenaagultom@gmail.com
}

\section{Latar Belakang}

Dokumentasi keperawatan merupakan unsur penting dalam sistem pelayanan kesehatan, karena adanya dokumentasi yang baik, informasi mengenai keadaan kesehatan pasien dapat diketahui secara berkesinambungan. Disamping itu dokumentasi merupakan dokumen legal tentang pemberian asuhan keperawatan.Menurut Häyrinena (2010), asuhan keperawatan merupakan hal sangat penting bagi seorang perawat. Kemampuan memberikan pelayanan yang baik serta kemudian dapat secara efektif mengkomunikasikan tentang perawatan pasien tergantung pada seberapa baik kualitas informasi yang diberikan serta dokumentasi yang disediakan untuk dimanfaatkan oleh semua profesional kesehatan dan antar bidang pelayanan kesehatan.Dokumentasi asuhan keperawatan adalah suatu catatan yang memuat seluruh data yang dibutuhkan untuk melakukan pengkajian menentukan diagnosis keperawatan,perencanaan keperawatan, tindakan keperawatan, dan penilaian keperawatan yang disusun secara sistematis, valid, dan dapat dipertanggungjawabkan secara moral danhukum (Zaidin Ali, 2009)

Pelaksanaan dokumentasi keperawatan merupakan salah satu alat ukur untuk mengetahui, memantau, dan menilai suatu pelayanan asuhan keperawatan yang dilakukan oleh rumah sakit (Fischbach, 1991). Dokumentasi keperawatan tidak hanya mencerminkan kualitas perawatan saja tetapi membuktikan pertanggunggugatan setiap tim keperawatan (Potter \& Perry, 2005). Oleh karena itu, jika kegiatan keperawatan tidak didokumentasikan dengan baik, akurat, obyektif,dan lengkap serta sesuai dengan standar asuhan keperawatan maka sulit untuk membuktikan bahwa tindakan keperawatan telah dilakukan dengan benar (Gillies, 2000; Carpenito, 1999).Keberhasilan pendokumentasian asuhan kepera-watan sangat dipengaruhi oleh seorang perawatsebagai ujung tombak dalam memberikan asuhan keperawatan (Potter \& Perry, 2005). Menurut Gibson (1996) dalam Suratun (2008) bahwa faktor individu yang memengaruhi perilaku kerja antara lain umur, lama kerja, pendidikan, dan pelatihan. Produktivitas seorangpekerja menurun dengan bertambahnya umur, sedangkan lama kerja mempunyai hubungan yang positif terhadap produktivitas pekerjaan. Siagian (2002) menyatakan bahwa makin tinggi tingkat pendidikan seseorang makin besar keinginan untuk memanfaatkan pengetahuan dan keterampilan. Pelatihan merupakan bagian dari proses pendidikan untuk meningkatkan pengetahuan dan keterampilan (Notoatmodjo, 2003). 


\section{Metode}

Jenis metode yang digunakan dalam penelitian ini adalah literatur review dengan menggunakan beberapa sumber dari e-jurnal,ebook,buku .Lalu mengangkumnya dan menjelaskan dengan sedemikian rupa agar mudah dipahami oleh pembaca .

\section{Hasil}

Hasil yang diperoleh dari pengkajian diatas adalah dalam kelengkapan dokumentasi keperawatan dipengaruhi oleh faktor individu anatar lain perilaku kerja antara lain umur, lama kerja, pendidikan, dan pelatihan. Produktivitas seorangpekerja menurun dengan bertambahnya umur, sedangkan lama kerja mempunyai hubungan yang positif terhadap produktivitas pekerjaan

\section{Pembahsan}

Dokumentasi keperawatan sebagian besar lengkap dikarenakan ada beberapa alas an diantaranya yaitu pada system pendokumentasian rumah sakit sudah ada kebijakan untuk melengkapi dokumentasi keperawatan, format dokumentasi sudah tersedia, adanya supervisi yang dilakukan, para perawat sudah pernah diberikan pelatihan dari pihak rumah sakit dan sudah terbudayanya pendokumentasian yang harus lengkap untuk menunjang mutu pelayanan dari pada rumah sakit. Semakin tertatanya manajemen asuhan keperawatan semakin dokumentasinya lengkap (Musiana dan Manurung, 2011).Terjadi perbedaan pada kelengkapan dokumentasi keperawatan pada masing-masing ruangan, ini dapat terjadi dikarenakan data dari indikator rawat inap yang didapat tentang hasil dari indikator BOR pada ruangan dengan metoda asuhan keperawatan modular yaitu VIP A dan VIP B sangat tinggi dan sudah melebihi dari standar ideal yang ditetapkan dari pihak manajemen Rumah Sakit, dan ini dapat menjadi faktor dari terjadinya perbedaan kelengkapan dokumentasi keperawatan yang dimana karena kapasitas pasien yang melebihi dan menjadikan pelaksanaan dari asuhan keperawatan yang salah satunya pendokumentasian dilakukan secara tidak maksimal. Itulah sebabnya mengapa dalam hal ini terjadi perbedaan. Hal ini bisa saja terjadi, banyaknya faktor yang mempengaruhi ketidaklengkapan dokumentasi keperawatan misalnya motivasi, beban kerja, tenaga keperawatan, lingkungan kerja, waktu dan kurangnya supervisi dari pihak manajemen rumah sakit (Widyaningtyas, 2012).

\section{Usia}

Pendapat Gibson (1996) dalam Suratun (2008) yang mengemukakan bahwa pekerja yang lebih tua dianggap lebih cakap secara teknis, lebih banyak pengalaman dan lebih bijaksana dalam pengambilan keputusan.

\section{Pendidikan}


Hal ini sesuai dengan pendapat Gibson (1996) dalam Suratun (2008) yang mengemukakan bahwa tingkat pendidikanyang tinggi umumnya menyebabkan seseorang lebih mampu dan bersedia menerima tanggung jawab. Sedangkan Siagian (2002) menjelaskan bahwa makin tinggi pendidikan seseorang makin besar keinginan untuk memanfaatkan pengetahuan dan keterampilan. Penelitian ini didukung pula oleh penelitian Fizran dan Mamdy (2002) yang mendapatkan bahwa tingkat pendidikan berhubungan secara bermaknadengan kinerja perawat dalam pendokumentasiankeperawatan serta penelitian Usman dan Tafal (2002) yang mengemukakan bahwa tingkat pendidikan berhubungan secara bermakna dengan motivasi perawat dalam penerapan proses keperawatan.

\section{Lama Berkerja}

Teori Nursalam, 2008 bahwa semakin lama masa kerja perawat maka semakin banyak pengalaman perawat tersebut dalam memberikan pelayanan terhadap pasien salah satunya yaitu dokumentasi keperawatan. Lama masa kerja perawat sangat berpengaruh pada kemampuan dan pengalaman perawat, kemampuan perawat dalam melakukan tindakan keperawatan akan meningkat karena menggunakan pengalaman masa lalu dan menerapkan pengetahuan yang relevan dalam setiap tindakan dan pengambilan keputusan (Potter \& Perry, 2005). Hal ini akan mempengaruhi dalam kelengkapan dokumentasi asuhan keperawatan.

\section{Pelatihan}

Sesuai dengan pendapat Noto-atmodjo (2003) yang menyatakan pelatihan merupakan bagian dari proses pendidikan untuk peningkatan pengetahuan dan keterampilan kerja. Hal ini didukung oleh penelitian Fizran dan Mamdy (2002) yang mendapatkan bahwa pelatihan berhubungan secara bermakna dengan kinerja perawat dalam pendokumentasian keperawatan dan penelitian Soetisno dan Christophora (2000) yang menunjukkan bahwa ada pengaruh positif dari pelatihan pada kelengkapan dokumentasi keperawatan.

\section{Jenis Kelamin}

Menurut Tawi (2008), jumlah perawat wanita sampai saat ini masih lebih banyak dari pada pria. Ini dikarenakan wanita dalam memberikan pelayanan keperawatan sangat teliti dan sabar. Didalam melakukan dokumentasi keperawatan wanita juga lebih bisa melakukan daripada pria. Dikarenakan wanita mengerjakannya dengan teliti dan sabar.Hal ini sejalan dengan Akhyar (2008) dimana budaya-budaya tertentu yang mempengaruhi hal-hal yang berhubungan dengan keperawatan, meskipun secara rasional antara laki-laki dan wanita akan mampu memberikan pelayanan keperawatan kepada klien. Namun tetap banyak anggapan bahwa pekerjaan perawat merupakan pekerjaan wanita,karena dianggap peran wanita sebagai perawat akan lebih baik dimana wanita memiliki sifat yang lebih lembut, teliti, rajin, dibandingkan dengan pria yang memiliki sifat lebih praktis. 


\section{Beban Perkerjaan}

Hasil penelitian menunjukkan bahwa sebagian besar perawat yang mempunyai beban kerja tinggi tidak melakukan pendokumentasian dengan lengkap. Hasil juga menunjukkan terdapat hubungan yang bermakna antara beban kerja dengan kelengkapan pendokumen-tasian asuhan keperawatan. Berdasarkan hasil penelitian dari semua perawat yang mempunyai beban kerja tinggi tersebut hanya 16,7\% yang melakukan pendokumentasian dengan lengkap. Hasil penelitian ini sejalan dengan pendapat Ilyas (2012) bahwa beban kerja perawat yang tinggi memengaruhi produktivitas kinerja perawat termasuk ke-giatan pendokumentasian asuhan keperawatan. Hal ini juga sesuai pernyataan Sochalski (2004), semakin banyak jumlah pasien akan meningkatkan beban kerja dan pada akhirnya akan berpengaruh terhadap kualitas pelayanan. Begitu halnya akibat dari kekurangan tenaga akibat penyebaran dan alokasi yang tidak merata menyebabkan beban kerja meningkat dan risiko terjadi penurunan kualitas pelayanan keperawatan (Duffield, et al 2011).Kelengkapan pendokumentasian asuhan keperawatan juga disebabkan oleh tingginya beban kerja perawat setiap shift. Hasil penelitian bebankerja dilihat berdasarkan shift menemukan bahwa shift pagi dan shift sore rata-rata perawatmempunyai beban kerja tinggi. Hal ini diperkuatoleh hasil penelitian Mobiliu (2005) yang menyatakan bahwa adanya keterkaitan antara shift pagi dengan kualitas pendokumentasian dibanding shift sore dan malam. Hasil penelitianjuga memperlihatkan lama waktu dinas perawat berlebih dari full time ekuivalen (FTE) perawat untuk shift pagi, shift sore, dan shift malam. Hal lain yang mengindikasikan beban kerja perawat tinggi adalah peneliti menemukan 6 orang perawat terpaksa harus double shift, hal itu dilakukan karena banyaknya kegiatan perawat terutama shift pagi dan sore sehingga memengaruhi pelaksanaan pendokumentasian asuhan keperawatan.

\section{Kesimpulan}

Pendokumentasian adalah pekerjaan mencatat atau merekam peristiwa dan objek maupun aktifitas pemberian jasa (pelayanan) yang dianggap berharga dan penting. Proses Keperawatan Sebagai kerangka kerja Dokumentasi. Dalam pendokumentasian, informasi yang penting harus dicatat secara berkesinambungan dan dievaluasi secara periodik untuk mengetahui dan menilai perkembangan masalah pasien. Hal yang perlu didokumentasikan meliputi data hasil pengkajian masalah kesehatan pasien sampai dengan evaluasi keperawatan. 


\section{Daftar Pustaka}

Ernawati dwi .dkk.2020.Hubungan Beban Kerja Perawat Dan Pelaksanaan Dokumentasi Asuhan Keperawatan Metode EMR (Eletronid Medical Record ) Di Ruang Rawat Inap RS Premier Surabaya.Jurnal Ilmial Keperawatan

Panjaitan Lasma Sri Rejeki .dkk.2015.Perbedaan Kelengkapan Dokumentasi Antara Metoda Medular Dan Metoda Tim Di RS Mitra Husada Pringsewu .Jurnal Keperawatan .

Noorkisiani .dkk.2015.Faktor -Faktor Yang Berhubungan Dengan Kelengkapan Dokumentasi Keperawatan .Jurnal Keperawatan Indonesia .

Mayasari Intan ,2016.Naska Plubilasi ,Hubungan Beban Kerja Yang Dilaksanakan Perawat Dengan Kelengkapan Dokumentasi Asuhan Keperawatn Di Ruang Rawat Inap Rumah Sakit PKU Muhammadiyah Yogyakarta .Program Studi Ilmu Keperwatan .Fakultas Keperawatan .Universitas Aisyiyah .

Eriyanti, Hj.2020.Buku Ajar Dokumentasi Keperawatan .Medan.Sekolah Tinggi Ilmu Kesehatan Binalita Sudama Medan .

R.H.Simamora. 2009. Dokumentasi Proses Keperawatan. Jember University Press

Nursalam. 2011. Manajemen keperawatan aplikasi dalam praktek keperawatan profesional. Edisi 3. Jakarta: Salemba Medika.

Radiani, E. 2009. Motivasi perawat dalam pendokumentasian asuhan keperawatan di puskesmas rawat inap Kabupaten Ciamis. Universitas Diponegoro.

Siwanto L.M.Harmain .dkk.2013.Faktor -Faktor Yang Berhubungan Dengan Kelengkapan Pendokumentasi Keperawatan.Jurnal Keperawatan Indonesia, 